\title{
REPLACEMENT OF WORKERS DURING STRIKES
}

Since NLRB v. Mackay Radio o Tel. Co. ${ }^{1}$ it has been the settled rule in labor law that an employer may hire permanent replacements for his workers who are striking to force compliance with the union's collective bargaining demands ${ }^{2}$ (economic strikes). There are some practical considerations which may restrain the employer from exercising his right. He may have a large stockpile of goods and may be indifferent to a shutdown. Or, he may desire to hire replacements, but the general condition of the labor market and the unwillingness of laborers to become strikebreakers ${ }^{3}$ may deter him from doing so. ${ }^{4}$ Despite these difficulties permanent replacement during economic strikes is a widespread practice which has great impact on both the worker and the union. ${ }^{5}$ Generally, a striking employee has a right to reinstatement after the strike is over. ${ }^{6} \mathrm{He}$ loses this right, however, when he is permanently

1. 304 U.S. $333,345-46$ (1938).

2. See, e.g., Philip Carey Mfg. Co. v. NLRB, 331 F.2d 720, 722-29 (6th Cir.), cert. denied, 379 U.S. 888 (1964); The employer is limited only by his duty not to discriminate against the union. See, e.g., Arthur J. Wiltsie, 85 NLRB 58 (1949), enforced, sub nom Ann Arbor Press v. NLRB, 188 F.2d 917 (6th Cir.), cert. denied, 342 U.S. 859 (1951).

3. "A scab is a two-legged animal with a corkscrew soul, a waterlogged brain, a combination backbone of jelly and glue. Where others have hearts, he carries a tumor of rotten principles." Jack London, C.I.O. News, September 20, 1946.

4. Furthermore, there is a conflict among the circuits as to whether an employer can pay permanent replacements more than his last offer to the union. The Sixth Circuit has ruled that they may be offered slightly higher wages. Pacific Gamble Robinson Co. v. NLRB, 186 F.2d 106, 109 (6th Cir. 1950). The Tenth has found that such an offer discriminates against the union and is evidence of an employer bargaining violation. NLRB v. St. Clair Lime Co., 315 F.2d 224, 228 (10th Cir. 1963); NLRB v. Southwestern Porcelain Steel Corp., 317 F.2d 527, 531 (10th Cir. 1963). If the later view is, as seems likely, ultimately accepted, the employer will be further prevented from exercising his right to hire replacements.

5. For example, in October 1962, the Teamsters were certified as the bargaining representative of a unit of twenty-two employees. After bargaining through December, the union called a strike on January 4. Three days later all twenty-two employecs were permanently replaced. Hot Shoppes, Inc., 146 NLRB 802 (1964). With a larger or more skillcd work force, the effect of the replacement rule is less dramatic.

6. Section 2(3), 49 Stat. 450 (1935), 29 U.S.C. $\& 152(3)$ (1964) preserves the strikcr's status as an "employee" who is protected by the Labor Act. See also, Editorial "El Imparcial," Inc., 123 NLRB 1585 (1959); Kitty Clover, Inc., 103 NLRB 1665, enforced, 208 F.2d 212 (8th Cir. 1953). However, the employer is under no duty to reinstate a striker whose job has been deleted for economic reasons, NLRB v. National Die Casting Co., 207 F.2d 344 (7th Cir. 1953); who has failed to make within a reasonable time an unconditional request for reinstatement, NLRB v. Brown \& Root, 203 F.2d 139 (8th Cir. 1953), Crosby Chems., Inc., 105 NLRB 152 (1953); or who is guilty of strike misconduct, Southern S.S. Co. v. NLRB, 
replaced. ${ }^{7}$ The possibility of replacement obviously must be taken into account by union members considering a strike vote. The fear of permanent replacement has been intensified by the NLRB's practice of deferring completely to the employer's classification of the replacement as permanent or temporary. ${ }^{8}$

In spite of the obvious importance of any replacement rule the first statement of the present rule was not very well considered. In Mackay the Supreme Court held that management's selective replacement of union leaders violated section $8(a)(3)$ by discriminating against union members. Then followed the famous dictum that the employer has "the right to protect and continue his business" by permanently replacing economic strikers, and "he is not bound to discharge those hired to fill the places of strikers. ..." This dictum was consistent with the common law rule that an employer had no duty to rehire an employee who stopped work for any reason. ${ }^{10}$ But the Wagner Act was passed to change many of the aspects of the previous law governing employment relationships. ${ }^{11}$ It should not have been sufficient to rely upon the common law in Mackay. The Labor Board in Mackay did not discuss the basis of the permanent replacement rule and, in fact, did not even focus on the general question of replacement. Instead, the Board inquired

316 U.S. 31 (1942) (mutiny), NLRB v. Fansteel Metallurgial Corp., 305 U.S. 240 (1939) (violence during a sitdown strike), W. L. Mead, Inc, 113 NLRB 1040 (1955) (economic strike in breach of a no-strike clause). However, the employer must reinstate those strikers whose misconduct he has condoned. NLRB v. E. A. Labs., Inc, 183 F.2d 885 (2d Cir.), cert. denied, 342 U.S. 871 (1951).

In NLRB v. Thayer Co., 213 F.2d 748 (Ist Cir.), cert. denied, 348 U.S. 883 (1954), Judge Magruder set out the thesis that 1 ) in an economic strike, in which there was no unfair labor practice, an employee discharged for conduct bejond the protection of $\$ 7$ could not be reinstated but 2) in an unfair labor practice strike, the Board could reinstate a striker even if his conduct was beyond the protection of $\$ 7$ so long as he was not discharged "for cause" under § 10 (c). Judge Bazelon adopted the latter strain of this argument in Local 883, UAW v. NLRB, 300 F.2d 699 (D.C. Cir.), cert. denied, 370 U.S. 911 (1962). See also, Cox, The Right to Engage in Concerted Activities, 26 IND. L. REv. 319, 324 n.24 (1951).

7. See, e.g., Cranston Print Works Co., 115 NLRB 537, 567 (1956). But see Marjdale Prods. Co., 133 NLRB 1232 (1961), where new employees were found not to be "replacements" because they would have been hired regardless of the strike.

8. See, e.g., The Texas Co., 93 NLRB 1358, 1362 (1951), in which the Board held that the employer's assurance of permanent employment was sufficient despite the fact that the replacement had to serve a probationary period. The Board defers to management's characterization because of the difficulty of determining the precise relationship between employer and employee. For example, employment contracts are seldom made. Sce text accompanying note 43 infra.

9. 304 U.S. at 345 .

10. See Adair v. United States, 208 U.S. 161 (1908); Union Pac Ry. v. Ruef, 120 Fed. 102 (C.C.D. Neb. 1902). See generally Note, 24 U. VA. L. REv. 661 (1933).

11. See, e.g., NLRB v. Jones \& Laughlin Steel Co., 301 U.S. 1, 48-49 (1937). 
into only the narrow issue of discriminatory employment. ${ }^{12}$ However, in a reply brief to the Supreme Court, ${ }^{13}$ the Board accepted Mackay's assertion that as a public utility it had a right and duty to hire permanent replacements. ${ }^{14}$ The rule which emanated from the Mackay case was not litigated before the Board and was inadequately argued before the Court. Despite this lack of consideration, the dictum has been followed blindly. ${ }^{15}$ In view of its background and its continuing impact in economic strikes the permanent replacement rule should now be reconsidered.

Replacement rules might be viewed as tools to establish bargaining equality between management and labor. For example, the NLRB might allow only temporary replacements if it believed that labor needed greater bargaining power. ${ }^{16}$ Setting aside the difficulties of constructing a series of rules designed to equalize the positions of employer and employee, such an approach is not now available. As the Supreme Court stated in American Ship Bldg. Co. v. NLRB, ${ }^{17}$ the Board does not have "a general authority to assess the relative economic power of the adversaries in the bargaining process and to deny weapons to one party or the other because of its assessment of that party's bargaining power." 18 In order to determine the legality of a lockout after a bargaining impasse, the Supreme Court turned to the text and legislative history of the LMRA.

Similarly, instead of being judged in terms of bargaining power, replacement rules must be judged in terms of those provisions of the Labor Act which define allowable employer activity, in particular, section $8(a)(3),{ }^{19}$ which proscribes employer "discrimination in regard to hire or tenure of employment or any term or condition of employ. ment to encourage or discourage membership in any labor organiza.

12. Mackay Radio \& Tel. Co., I NLRB 201, 216-17 (1936).

13. The pertinent portion is reprinted in Boudin, The Rights of Strikers, 35 ILl. L. REV. 817, 831 (1941).

14. Brief for Respondent, p. 24, NLRB v. Mackay Radio \& Tel. Co., 304 U.S. 333 (1938).

15. See, e.g., Adams Bros. Manifold Printing Co., 17 NLRB 974, 980 (1939).

16. This argument would have particular validity in the context of permanent replacement. As a weapon for management, permanent replacement is most cffective against weak unions. In general, the strength of a labor organization is inversely proportional to the number of non-union workers capable of filling strikers' jobs. Thus, replacement, which must draw upon such workers, can be effectively utilized against only wcak unions; against strong unions it is an impotent management weapon.

17. 380 U.S. 300 (1965).

18. Id. at 317 .

19. 49 Stat. 452 (1985), 29 U.S.C. $\$ 158(a)(8)$ (1964). See Mackay Radio \& Tcl. Co., 1 NLRB 201, 216-17 (1936), for the suggestion that the replacement rules should be analyzed under $\& 8(\mathrm{a})(\$)$. 
tion." A violation of this section is usually established by showing an overt act or statement reflecting anti-union discrimination. ${ }^{20}$ However, direct proof of the employer's intent is not always required; in some circumstances discrimination can be presumed from his conduct.21

Recently, in two separate cases, the Supreme Court attempted to establish guidelines for the use of such a presumption. Mr. Justice Stewart, writing for the majority in American Ship Bldg., stated that the Board could find discriminatory intent in employer conduct which is "prejudicial to union interests" and is "devoid of significant economic justification." 22 The application of this standard would rarely, if ever, lead to the presumption of discriminatory intent. For example, even selective discharge of union leaders, clearly illegal under section 8(a) (3), ${ }^{23}$ could have "significant economic justification." The employer may desire to rid his plant of the union in order to lower wages.

The test of $N L R B$ v. Brown ${ }^{24}$ differs fundamentally ${ }^{25}$ from that of American Ship Bldg., although the two cases were decided on the same day by the same majority. In Brown, the Court stated that illicit intent could be presumed from conduct that is "destructive of employee rights" and "devoid of significant service to any legilimate business end." 28 The qualification "legitimate" distinguishes the Brown test from the meaningless one of American Ship Bldg. This distinction was recognized by Mr. Justice Goldberg who concurred in both opinions. He disagreed with the American Ship Bldg. test and stated that only "legitimate economic interests of the employer" should be recognized.".7 In Brown, however, Mr. Justice Goldberg accepted the majority's formulation. ${ }^{28}$ The opinions in the two cases differ in another respect. Brown states explicitly that a violation of section $8(a)(3)$ can be found even in conduct which serves a legitimate business purpose if that purpose is outweighed by a prejudicial effect upon employees. ${ }^{20}$ Since the Supreme Court has in the past found violations despite a legitimate

20. For a collection of cases, see Radio Officers Union v. NLRB, 347 U.S. 17, 43 (19;5).

21. See NLRB v. Erie Resistor Corp., 373 U.S. 221, 228 (1963).

22. 380 U.S. at 311 .

23. See, e.g., NLRB v. Vapor Blast Mfg. Co., 287 F.2d 402 (7th Cir.), cert. denied, 368 U.S. 823 (1961).

24. 380 U.S. 278 (1965).

25. Some commentators have failed to recognize the difference. See, e.g., Oberer, Lochouts and the Law, 51 CoRNell L.Q. 193, 209 (1966).

26. 380 U.S. at 286. (Emphasis supplied.)

27. Id. at 340 .

28. Id. at 292-94.

29. "[G]onduct so inherently destructive of employee rights could not be saved from illegality by an asserted overriding business purpose pursued in good faith." Id. at 287. 
business interest, ${ }^{30}$ the Brown test corresponds more closely to past decisions. If Brown is to be followed the legitimate business interest served by the permanent replacement rule must be compared with its impact on employee rights granted by the Labor Act.

The hiring of permanent replacements may have three principal effects on strikers. Allowing the employment of permanent replacements enables management to continue its business during the work stoppage and thus weakens the bargaining position of the union. ${ }^{31}$ But the Labor Act does not guarantee employees a maximum bargaining position, ${ }^{32}$ and such an effect could not serve as the basis of a section 8(a)(3) violation. The other two effects of permanent replacement, however, do impinge upon guaranteed employee rights.

Section 13 of the LMRA expressly refers to labor's "right to strike." Other sections of the Act reinforce this fundamental guarantee..$^{33}$ But its full exercise is restrained by permanent replacement. At times, even the threat of such replacement may prevent the calling of a work stoppage or cause a striking union to surrender to management's demands. For the strike may result in the permanent loss of members' jobs and the elimination of pension, seniority or other rights acquired through previous service.

A second effect of the Mackay rule undermines the union's status as bargaining representative. Replacements are likely to be anti-union and may, if permanent, vote in certification elections held during a strike. ${ }^{34}$ An employer can hire, and characterize as "permanent," a sufficient number of strikebreakers to force the union's decertification. This weapon gives him control over the decision whether or not his plant will be unionized by allowing him to nullify the strikers' choice of a bargaining representative. Of course, if replacements are, in fact, permanent they deserve a voice in the organization of the plant. However, the

30. NLRB v. Erie Resistor Corp., 373 U.S. 221 (1963).

31. So, too, does hiring temporary replacements. On the other hand, temporary replacements do not impinge upon guaranteed employee rights. See text accompanying notes 40.43 infra.

32. For example, the right to strike is limited by the sixty day waiting period of $\$ 8(\mathrm{~d})$, 61 Stat. $142-43$ (1947), 29 U.S.C. $\S 158$ (d) (1964). Also, the union is not always granted the right to determine the timing and duration of every work stoppage. See, American Ship Bldg. Co. v. NLRB, 380 U.S. 300, 310 (1965).

33. $\S \S 7,8(a)(1), 8(a)(3), 2(3)$. See also NLRB v. Erie Resistor Corp., 378 U.S. 221, 223 (1963).

34. Originally, replacements were ineligible to vote. A. Sartorius \& Co., 10 NLRB 499 (1938), reversing 9 NLRB 19 (1938). Permanent replacements were franchised only after Mackay was decided and their jobs were secure. Rudolph Wurlitzer Co., 32 NLRB 168 (1941). 
Labor Board usually defers completely to the employer's characterization. ${ }^{35}$ It is extremely easy for the employer to call a temporary employee permanent. And if the replacements are really temporary their votes in a certification election dilute the striking employees' rights to choose their own bargaining representative. This choice is a fundamental one, guaranteed by sections 7 and 8 of the Labor Act.

The facts underlying United Rubber Workers ${ }^{36}$ provide an example of this impact. In that case, the union won a representation election by a substantial margin but failed to negotiate a collective bargaining agreement. A strike followed, and the employer reacted by permanently replacing most of the union members. A year later, another certification election was held. With the replacements voting, the union was defeated 288 to 5 .

In 1959 Congress mitigated these anti-union effects by amending section 9(c)(3) of the Labor Act. The Board was given the power to allow permanently replaced strikers to vote in certification elections during the strike. ${ }^{37}$ (Temporarily replaced and unreplaced strikers had always been eligible to vote. $)^{38}$ However, Congress did not disenfranchise the permanent replacements, nor did it prohibit the employer from characterizing the replacements as he pleased. Although the amendment makes the employer's job more difficult, he may still undermine the

35. At present, for voting purposes, the Board presumes that all replacements are permanent. Pacific Tile \& Porcelain Co., 137 NLRB 1358, 1360 (1962). For the difficult tack facing a union attempting to challenge this presumption, see Bowman Transp., Inc., 142 NLRB 1093 (1963).

36. 121 NLRB $1439,1442-43$ (1958).

37. "Employees engaged in an economic strike who are not entitled to reinstatement shall be eligible to vote under such regulations as the Board shall find are consistent with the purposes and provisions of this Act in any election conducted within twelve months after the commencement of the strike." 73 Stat. 542, 29 U.S.C. $\$ 159$ (c)(2) (1964). Alusough the Board has the power to make rules, [\$ 6, 49 Stat. 452 (1959), 29 U.S.C. $\S 156$ (1964); Peck, The Atrophied Rule-Making Powers of the National Labor Relations Boord, 70 YALE L.J. 729, 751-52 (1961)], it has not chosen to exercise it. W. Wilton Woods, Inc, 127 NLRB 1675 (1960). Instead, despite an attempt to compel it to make rules in accordance with the requirements of the Administrative Procedure Act, Boire v. Miami Herald Pub. Co., 343 F.2d 17 (5th Cir. 1965), the Board has proceeded by adjudication.

In Pacific Tiles \& Porcelain Co., 137 NLRB 1358 (1958), the Board acknowledged the settled rule that once an economic striker obtains permanent cmployment, he is no longer entitled to vote. See, e.g., Horton's Laundry, Inc, 72 NLRB 1129, $1135-37$ (1947). However, the Board also recognized the rule that the striker's intent to return to work was the kcy factor. See Oates Bros., Inc, 127 NLRB 1674 (1960). Because of the difficulty of proving the striker's intent, the Board ruled that it would presume that all strikers intended to return to work. Pacific Tile \& Porcelain Co., supra at 1359. As a result, replaced strikers are entitled to vote.

38. A. Sartorius \& Co., 10 NLRB 493 (1938), reversing 9 NLRB 19 (1938). 
union's majority by hiring replacements, characterizing them as permanent, and thereby swelling the electorate. ${ }^{30}$

To offset these anti-union effects the employer may offer various legitimate business justifications. Permanent replacements have always been considered necessary to promote one fundamental employer interest-the right to "protect and continue" his business during a strike. ${ }^{40}$ This legitimate business purpose, however, may be served by temporary replacements also. Since only permanent replacements have an anti-union effect, the Mackay rule could be justified only if permanent replacements serve a business purpose which could not be served by temporary replacements. This justification might be valid if it could be shown that the offer of permanent work is necessary to induce a replacement to accept employment. ${ }^{41}$ There are two possible ways to evaluate this justification.

Perhaps an investigation of the employer's labor market would show the necessity of offering permanent employment. In such an inquiry conditions in both the national and local labor markets would have to be considered. Another relevant statistic would be the number of qualified applicants for replacement work. In addition, their past employment history, such as prior wages and months out of work, would be relevant. But even this summary listing of the factors which the Board would have to investigate highlights the difficulty, if not the impossibility, of determining necessary inducement from a study of the labor market. Were the Board to make such an examination in every case, it would have little time to devote to its other responsibilities.

Perhaps the employer should be allowed to show necessary inducement by showing that he has in fact induced the employee to work by giving him benefits greater than temporary employment. It is probably valid to assume that if the employer has given some substantial benefits it was necessary to do so. ${ }^{42}$ But to prove that the employer has given something more than temporary employment he must show that the employee has an enforceable claim against him to assure tenure extending substantially beyond the end of the strike. If the replacement has

39. See NLRB v. United Furniture Workers, 337 F.2d 936 (2d Cir. 1964), wherc, (lespite the new voting rules, the union was displaced.

40. NLRB v. Mackay Radio \& Tel. Co., 304 U.S. 333, 345 (1938).

41. It has been assumed that permanent employment is often a necessary inducement to a replacement. See Note, 27 U. CFr. L. REv. 368, 376 (1960). See also Comment, $60 \mathrm{Nw}$. U.L. REv. 689, 713 (1965); Intermediate Report and Recommended Order, Hot Shoppcs, Inc, 146 NLRB 802, 807, 835 (1964).

42. Of course such an arrangement would not preclude the employer from making permanent contracts when they were not necessary so that he could displace the union employees; however, it would put a cost on, and hopefully deter, such displacement. 
no such claim, although the employer may characterize him as "permanent," he has no greater rights, and therefore has been offered no greater inducement than a temporary replacement. Similarly, without such enforceable rights, the characterization has cost the employer nothing and he is free to apply it solely to achieve anti-union effects. Todny, the usual employment relationship neither serves as the basis for proving necessary inducement nor imposes any cost upon the employer. "The generality of employees have no employment contracts, and are not employed for definite terms." 43 The employer is free to release "permanent" replacements, and only a desire to undermine the union binds him to retain them until after the strike is settled.

Necessary inducement could be established, therefore, only if the replacements obtained contracts for a specific term of employment. However, in addition to the purely business considerations which would make an employer reluctant to enter into such a contract, its legal consequences under the Labor Act virtually preclude its use. It is clear that the provisions of a replacement contract potentially would conflict with any subsequent agreement that might be reached between the employer and the union. NLRB v. J.I. Case ${ }^{4 t}$ makes it equally clear that when such a conflict occurs the individual contract must yield to the collective one. Thus, the contract offered to a replacement may be no contract at all, since management would not be required to honor it in the face of a subsequent collective agreement. ${ }^{45}$

An employment contract for a specific term would also appear to violate the proscription against granting superseniority to replacements announced by the Supreme Court in Erie Resister Co. v. NLRB. In that case, replacements had been granted twenty years seniority in order to assure their employment after the end of the strike. The Court ruled that the grant of superseniority violated section $8(a)(3)^{47}$ even if it had been necessary to induce the replacements to accept employment.

43. Hot Shoppes, Inc., 146 NLRB 802, 832 (1964).

44. 321 U.S. 392 (1944).

45. Furthermore, it is unlikely that management would have to pay damages for the breach of the individual contract. J. I. Case v. NLRB, supra note 44 at 337, 338, 342. Such payment by management would vitiate the effect of superseding the individual contract by the collective one.

46. 373 U.S. 221 (1963).

47. Id. at 231. Furthermore, if the emplojer insists that the union accept a superseniority plan, he violates his duty to bargain imposed by $\S 8(a)(5) 49$ Stat. 453 (1935), 29 U.S.C. § 158(a)(5) (1964). See Philip Carey Mfg. Co. v. NLRB, 331 F.2d 720 (Gth Cir.), cert. denied, 379 U.S. 888 (1964); Griffin Wheel Co. v. NLRB, 320 F.2d 656 (7th Cir. 1963). It should be noted that the rationale for $\$ 8(a)(\$)$ emplojed in Erie Resistor was expressly approved by the Supreme Court in Brown. See text accompanying and notes 28 and 29 supra. 
A contract which guaranteed the replacement employment for a period of months would have the same effect as a grant of superseniority. For example, if the replacement were given a five year contract, he would be retained in preference to the replaced striker even though the latter would have greater seniority. And, if layoffs became necessary during the term of the replacement's contract, other workers with greater seniority would lose their jobs before he would lose his.

The duty to bargain, imposed on the employer by section 8(a)(5), ${ }^{48}$ may also prevent him from entering into contracts of permanent employment. It is a common practice for the union to insist upon the reinstatement of strikers as a condition of the strike settlement. ${ }^{40}$ Since the parties may insist only upon those subjects about which there is a duty to bargain, ${ }^{50}$ and since no charges of unfair labor practice by the union have been found, it seems likely that no one has even questioned that there is a duty to bargain about reinstatement. Also Fibreboard Paper Prods. Co. v. $N L R B^{51}$ held that the employer has a duty to bargain about subcontracting unit work, and that he violated that duty by contracting without first consulting the union. The existence of a strike does not terminate the duty of both parties to bargain. ${ }^{62}$ Thus, Fibreboard would also seem to require the employer, as part of the strike settlement, to bargain about his adherence to any subcontracting arrangements made during the strike..$^{53}$ If there is a duty to bargain about subcontracting arrangements made during a strike, then there should also be a duty to bargain about permanent replacements hired during the strike since subcontracting and replacement decisions have the same effect upon the employees. If, as seems probable, such a duty exists, the employer would be committing an unfair labor practice by contracting with the replacements to keep them after the settlement of the strike. For by so contracting, the employer would make it difficult

48. 49 Stat. 453 (1935), 29 U.S.C. § 158(a)(5) (1964).

49. See The Philip Carey Mfg. Co., 140 NLRB 1103, 1105 (1963), enforced, 331 F.2d 720, 728 (6th Cir.), cert. denied, 379 U.S. 888 (1964). See also Gen. Counsel Ad. Decis, SR.1768, 1962 CCH LAB. L. REP. I $11,076$.

50. Allis-Chaimers Mfg. Co. v. NLRB, 213 F.2d 374, 376 (7th Cir. 1954).

51. 379 U.S. 203 (1964).

52. See, e.g., NLRB v. United States Cold Storage Corp., 203 F.2d 924 (5th Cir.), cert. denied, 346 U.S. 818 (1953); NLRB v. Remington Rand, Inc., 130 F.2d 919, 927 (2d Cir. 1942).

53. In Hawaii Meat Co. v. NLRB, 321 F.2d 397, 399 (9th Cir. 1963), the Ninth Circuit assumed that, upon the union's request, the employer would have to bargain about the continuation of such subcontracting. It is clear that the employer need not bargain about his initial decision either to subcontract, NLRB v. Abbott Publishing Co., 391 F.2d 209 (7th Cir. 1964), Shell Oil Co., I49 NLRB No. 22 (Oct. 29, 1964), or to hire replacenents, Times Publishing Co., 72 NLRB 676, 684 (1947), during the strike. 
to bargain in good faith about the reinstatement of the replaced strikers after the strike.

Two conclusions may be drawn from the discussion of permanent replacement. Either it can never serve a legitimate business interest (since offering a permanent position cannot be justified as necessary inducement to obtain replacements), or, when the offer might be justified as a necessary inducement it is illegal on other grounds. And since permanent replacement undermines employee rights guaranteed by the Labor Act, the current replacement rule employed by the Board for economic strikes is inconsistent with the requirements of section $8(a)(3)$ as interpreted in Brown.

Any argument for a different interpretation of $8(a)(3)$ based on Congress's 1959 amendment to section 9(c)(3) should be rejected. In 1959 Congress acted to mitigate the effects of the Mackay rule by providing that "[e]mployees engaged in an economic strike who are not entitled to reinstatement shall be eligible to vote under such regulations as the Board shall find are consistent with the purposes and provisions of this Act in any election conducted within twelve months after the commencement of the strike." "Ft Admittedly, when Congress used the words "economic strikers not entitled to reinstatement," it recognized the existence of the Mackay rule. But to read $9(c)(3)$ as an affirmance by Congress of the Mackay dictum would contradict the purpose of the 1959 amendment. ${ }^{55}$ Moreover, the elimination of the permanent replacement rule would not render section $9(c)(3)$ meaningless; it would still apply to workers who were not entitled to reinstatement for reasons other than permanent replacement. ${ }^{50}$

In addition to the requirements of section $8(a)(3)$, there exists another argument against the permanent replacement rule in economic strikes. It is the confusion that dissimilar replacement rules for economic and for unfair labor practice strikes visits upon labor and management. An unfair labor practice strike is a work stoppage protesting an employer's unfair labor practice. It may be called during the term of a collective agreement ${ }^{57}$ or may simply be a continuation of an

54. 73 Stat. 542 (1959), 29 U.S.C. $\S 159$ (c)(3) (1964).

55. See text accompanying note 37 supra.

56. For example, the employee might not be entitled to reinstatement because his job was deleted for economic reasons. See NLRB v. National Die Casting Co., 207 F 2d 344 (7th Cir. 1953). At present, the Board does not allow strikers who are not entitled to reinstatement because they are discharged for misconduct to rote. W. Wilton Wood, Inc, 127 NLRB 1675, 1677 (1960).

57. See, e.g., Kitty Clover, Inc, 103 NLRB 1665, enforced, 208 F.2d 212 (84h Cir. 1953). Also, Mastro Plastics Co. v. NLRB, 350 U.S. 270 (1956), held that unfair Jabor practice 
economic strike. ${ }^{58}$ The Board has always held that during unfair labor practice strikes only temporary replacements could be utilized ${ }^{\text {bD }}$ and that all strikers were, therefore, entitled to reinstatement. ${ }^{00}$ The existence of this rule and the permanent replacement rule for economic strikes makes it difficult for either party to know its rights when the union claims management has committed an unfair labor practice during an economic strike. ${ }^{21}$ The union would claim that the strike was an unfair labor practice strike, and management would claim it was an economic strike. If the union's allegation is later sustained by the NLRB, management will be required to give back-pay to those strikers who were permanently replaced after the date of the illegal practice and who were not reinstated. ${ }^{\text {o2 }}$ If, however, the union's claim is denied, the employer would not be liable for back-pay. Since the definition of an unfair labor practice is an uncertain matter, and since the NLRB and courts may not decide the case finally for years after the claimed viola. tion, management and labor are forced to bargain about the strike settlement without knowing their precise legal relationship. A replacement rule which would apply equally to unfair labor practice and economic strikes is desirable.

It is clear, though, that only temporary replacements can be allowed for unfair labor practice strikers. If the Board allowed permanent replacement it could not order the employer to give back-pay. And reinstatement with back-pay is the only effective sanction against an employer who has violated the Labor Act during the course of an economic strike. A cease and desist order, issued months after the violation, would not aid the union whose strike had been broken by the unfair practice.

strikes are limited neither by a no-strike clause in the collective bargaining agrecmont nor by the Labor Act's sixty-day cooling off period. 61 Stat. 142 (1947), 29 U.S.C. \& 158(d) (1964).

58. The Board's rule is that the unfair labor practice must prolong the cconomic strike. See, e.g., NLRB v. Guistina Bros. Lumber Co., 253 F.2d 371 (9th Cir. 1958). As long as one concurrent cause of the strike is an unfair labor practice, the strike may also have economic aims. KARD-TV, 122 NLRB 222 (1958). For a criticism of the Board's finding of per se prolongation of an economic strike and thus automatic conversion into an unfair labor practice strike, see Stewart, Conversion 'of Strikes-Economic to Unfair Labor Prac. tice: II, 49 U. VA. L. REv. 1297 (1963).

59. Scobell Chem. Co., 121 NLRB 1130, 1132, enforced, 267 F.2d 922 (1959). However, up to the time at which an economic strike is converted into an unfair labor practicc strike, the employer may hire permanent replacements. See R. J. Oil \& Ref. Co., 108 NLRB 641, 648 (1954).

60. Kitty Clover, Inc., I03 NLRB 1665, enforced, 208 F.2d 212 (8th Cir. 1958). Unfair labor practice strikers are entitled to vote, Times Square Stores Corp., 79 NLRB 861, 864 (1948), but their replacements are not. Tampa Sand \& Material Co., 137 NLRB 1549 (1962).

61. See generally Stewart, Conversion of Strikes: Economic to Unfair Labor Practice I \& II, 45 U. VA. L. REv. 1332 (1959), 49 U. VA. L. REv. 1297 (1968).

62. Maurice Embroidery Works, Inc., 111 NLRB 1143, 1160 (1955). 
To treat all strikes uniformly a temporary replacement rule must also be applied in economic strikes.

Considering all of these criticisms only a wooden application of stare decisis supports the retention of the Mackay rule. Therefore, despite twenty-eight years of adherence to a rule which allows permanent replacement, the Board or the Court should announce a new rule which allows only temporary replacement during economic strikes. ${ }^{03}$

63. For the same reasons, it would seem that a permanent replacement rule should not be applied in the lockout context. The anti-union effects would be the same as in the strike situation and the employer would likewise be unable to demonstrate a legitimate business purpose. In NLRB v. Brown, 380 U.S. 278 (1965), the union struck an emplojer who was a member of a bargaining association comprised of several revil stores. That employer hired replacements but retained them only during the strike. The Court held that the association's non-struck members could respond to the union's action by locking out their emplojees under NLRB v. Truck Drivers Loal Union (Buffalo Linen), 353 U.S. 87 (1957), and obtaining, like the struck member, temporary replacements. It was not decided, however, "whether the case would be the same had the struck employer exerciced its prerogative to hire permanent replacements for the strikers . . . and the non-struck employers had then hired permanent replacements for their locked-out emplojees." NLRB v. Brown, supra at 292 n.6. For the reasons enumerated in this Note, it is clear that neither the struck nor the non-struck member of a multi-emplojer bargaining association could show any legitimate business purpose in hiring permanent replacements. Furuhermore, such replacements should not be allowed in offensive lockouts. When the Supreme Court in American Ship Bldg. Co. v. NLRB, 380 U.S. 300 (1965) held that, after a bargaining impasse, the employer could lock out his employees to bring pressure to bear in support of his legitimate bargaining position, it expressly stated that it intimated no view on whether the employer could offensively lock out and then hire either temporary or permanent replacements. Id. at 308 n.8. Again, because he cannot demonstrate any legitimate business purpose to offset the anti-union effect, the employer should not be allowed to hire permsnent replacements. Finally, permanent replacements should not be permitted in lodsouts called by an employer who is fearful of unusual strike damage. The following are $e x$. amples of such defensive lockouts. Betts Cadillac-Olds, Inc, 96 NLRB 263 (1951) (preventing automobile from being half-repaired when the strike is called); Duluth Bottling Ass'n, 48 NLRB 1335 (1943) (avoiding spoilage from a sudden work stoppage); Link-Belt Co., 20 NLRB 227, $264(1940)$ (frustrating the seizure of a plant by a sit down strike). 